\title{
Seasonal Economic Instability in Canadian Metropolitan Areas
}

\author{
H. Craig Davis*
}

\section{INTRODUCTION}

Although research into urban economic problems has grown rapidly over the past few years, little of this attention to urban matters has been directed to the subject of urban economic instability. This lack of investigation can be partially explained by the absence of urban economic data and is in part attributable to the belief that urban instability problems arise from national fluctuations. If the latter are successfully counteracted, the argument goes, the former will be abated.

Changes in long term growth patterns aside, there are two types of economic fluctuations: seasonal and cyclical. The former here refer to deviations in economic employment about the average during a continuous twelve month period while the latter are deviations about the trend over a period of several years. The present paper is solely concerned with fluctuations of the seasonal variety. If indeed the causes of cyclical instability are national in scope, it may be the adverse affects of seasonal fluctuations that are the more readily mitigated by the policies of local government.

Specifically, the present paper is concerned with the following four questions regarding seasonal instability:

1) What is the extent of seasonal fluctuations in the major metropolitan areas?

2) Are the seasonal cycles of different sectors offsetting or mutually reinforcing?

3) To what degree is seasonal stability in urban areas correlated with economic diversity?

4) Do those sectors that are unstable vary between urban areas?

To the extent that available data will allow, answers to these questions in the Canadian context are attempted in the discussion below.

\section{SEASONAL FLUCTUATIONS IN EMPLOYMENT}

Monthly employment data for various sectors for a number of Canadian metropolitan areas are compiled and reported by Statistics Canada. ${ }^{1}$ The agency's mail survey covers all companies with 20 or more employees in any one month of the year. This includes multi-establishment firms of over 20 total employees in any one month. Unfortunately, no distinction is made in the data between full

*Associate Professor, Community and Regional Planning and Faculty of Commerce, The University of British Columbia, Vancouver, B.C., Canada. 
time and part time employees. Moreover, the percentage of total employment covered by the survey varies from one economic sector to another and coverage sectors are given only on provincial bases.

The total employment picture is further clouded by the fact that the survey excludes agriculture, fishing and trapping, education and related services, health and welfare services, religious organizations, private households, and public administration and defence. An additional problem arises from the fact that the number and designation of sectors for each metropolitan area generally varies in proportion to the size of the area. While for Toronto and Montreal upwards of 60 sectors are reported, only 30 are reported for Vancouver. For some of the smaller areas, employment data are provided for merely half a dozen sectors. For each of the nine different metropolitan areas discussed in this paper, the "metropolitan area" definitions of the Census of Population ${ }^{2}$ were adopted by Statistics Canada to define the regional unit.

In this section, we shall concentrate upon the three largest Canadian metropolitan areas: Toronto, Montreal and Vancouver. Together these three urban centres comprise approximately $30 \%$ of total Canadian population. From the data discussed above, 21 economic sectors common to all three areas can be established through aggregation. These sectors, with their $\mathrm{SIC}^{3}$ code definitions, are shown in Table II in the section immediately following.

Where time series observations are sufficient in number, fluctuations in economic activity can be decomposed into four components: 1) seasonal oscillations 2) cyclical movements, 3) trend effects and 4) irregularities. A seasonal index can be constructed from this decomposition by means of the calculation of a centred twelve month moving average. As mentioned, however, the data presently available extends only over the three years 1971-73. Thirteen of the thirty-six monthly observations would thus be lost in the calculation of a centred moving average. ${ }^{4}$ Further, in the analysis of monthly data on an annual basis for a three year period, cyclical and trend effects can be considered to be relatively inconsequential.

For the above reasons, a seasonal index was constructed simply by expressing total metropolitan employment in each month as a fraction of the annual average. The results relating to corresponding months of different years were then averaged to eliminate irregularities to the extent the data will allow. A seasonal employment index, SI, for each of the three major Canadian urban centres was thus calculated according to equation (1) and the results are shown in Table 1.

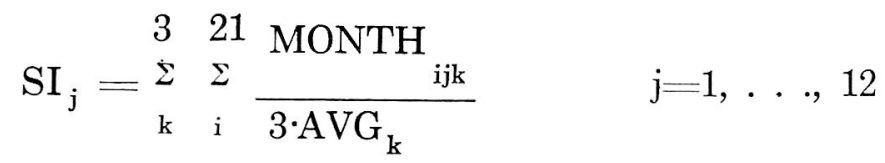

where MONTH $_{\mathrm{ijk}}=$ metropolitan employment in sector $\mathrm{i}$, month $\mathrm{j}$, year $\mathrm{k}$ and $\mathrm{AVG}_{\mathrm{k}}=$ annual average metropolitan employment in year $\mathrm{k}$.

The mean absolute deviation from the annual average was calculated from this index and, as seen from Table I, ranges from $1.66 \%$ for Montreal to $2.42 \%$ for Vancouver. Given annual average employment in Toronto, Montreal and Van- 
couver during this period at roughly $800,000,700,000$ and 400,000 respectively, the mean deviations of Table I imply monthly fluctuations of approximately 15,000, 12,000 and 8,000 man years for the three metropolitan areas.

It is difficult to construct estimates of seasonal unemployment from the figures in Table I, however, given the inadequacies of the data previously mentioned. The problem is further complicated by monthly variations in each metropolitan labour force due to changes in population size and labour participation rates. Accurate estimates of the extent to which seasonal unemployment exists in metropolitan areas is thus beyond the scope of the present paper and it may be concluded at this point only that the problem is of sufficient significance to warrant further investigation.

\section{SECTORAL SEASONAL INSTABILITY: PEAKS, TROUGHS AND ECO- NOMIC DIVERSITY}

In his discussion of seasonal fluctuations, Thompson argues the following: ${ }^{5}$ A priori, the case for industrial diversification as a stabilizing device would seem to hold varying promise. Seasonal patterns of the various industries are probably randomly distributed, that is, there are roughly as many seasonals with winter peaks as with summer peaks... Even unplanned, random diversification is likely to effect a substantial reduction in local seasonal instability.

\section{TABLE I}

Seasonal Employment Indices for the Major Metropolitan Areas, 1971-73

\begin{tabular}{lccc}
\hline \multirow{2}{*}{ Month } & \multicolumn{3}{c}{ Metropolitan Area } \\
\cline { 2 - 4 } & Toronto & Montreal & Vancouver \\
\hline January & 0.963 & 0.968 & 0.951 \\
February & 0.964 & 0.973 & 0.961 \\
March & 0.976 & 0.982 & 0.980 \\
April & 0.987 & 0.988 & 0.987 \\
May & 1.008 & 1.004 & 0.982 \\
June & 1.024 & 1.019 & 0.993 \\
July & 1.000 & 0.992 & 1.014 \\
August & 1.004 & 1.011 & 1.025 \\
September & 1.015 & 1.022 & 1.028 \\
October & 1.024 & 1.025 & 1.032 \\
November & 1.026 & 1.018 & 1.033 \\
December & 1.008 & 0.997 & 1.014 \\
\hline Mean Deviation & & & \\
from Annual & $1.84 \%$ & $1.66 \%$ & $2.42 \%$ \\
Average & & & \\
\hline
\end{tabular}


If Thompson is correct, we should expect to find from analysis of our data: a) that seasonal cycles among the economic sectors of each CMA are largely offsetting in their effects upon employment and b) a correlation between seasonal stability and economic diversity.

To test the first hypothesis, 1971-1973 monthly employment data for each of the metropolitan areas of Toronto, Montreal and Vancouver were analyzed. For each of the 21 sectors in each city, the three months of highest employment and the three months of lowest employment were determined. The results for the latest year, 1973, are shown in Table II. The general pattern of this year also emerges from similar analyses of the years 1971 and 1972.

TABLE II

PEAK AND NADIR EMPLOYMENT MONTHS FOR THE MAJOR METROPOLITAN AREAS, 1973

\begin{tabular}{|c|c|c|c|c|c|c|c|c|c|c|c|c|c|c|c|c|c|c|c|}
\hline \multirow{3}{*}{$\begin{array}{c}1960 \\
\text { S.I.C. } \\
100-139\end{array}$} & \multirow{3}{*}{$\begin{array}{l}\text { ECONOMIC SECTORS } \\
\text { 1. Foods }\end{array}$} & \multicolumn{6}{|c|}{ TORONTO } & \multicolumn{6}{|c|}{ MONTREAL } & \multicolumn{6}{|c|}{ VANCOUVER } \\
\hline & & \multicolumn{3}{|c|}{$\begin{array}{l}\text { Peak } \\
\text { Months }\end{array}$} & \multicolumn{3}{|c|}{$\begin{array}{l}\text { Nadir } \\
\text { Months }\end{array}$} & \multicolumn{3}{|c|}{$\begin{array}{l}\text { Peak } \\
\text { Months }\end{array}$} & \multicolumn{3}{|c|}{$\begin{array}{l}\text { Nadir } \\
\text { Months }\end{array}$} & \multicolumn{3}{|c|}{$\begin{array}{l}\text { Peak } \\
\text { Months }\end{array}$} & \multicolumn{3}{|c|}{$\begin{array}{l}\text { Nadir } \\
\text { Months }\end{array}$} \\
\hline & & 6 & 7 & 8 & 12 & 1 & 2 & 10 & 7 & 9 & 2 & 3 & 1 & 7 & 8 & 3 & 2 & 1 & 5 \\
\hline $140-147$ & 2. Beverages & 6 & 7 & 8 & 1 & 2 & 3 & 6 & 712 & 12 & 1 & 2 & 3 & 12 & 8 & 9 & 3 & 4 & 1 \\
\hline $270-274$ & 3. Paper \& Allied Ind. & 6 & 11 & 10 & 1 & 2 & 3 & 10 & 91 & 11 & 3 & 1 & 8 & 6 & 7 & 8 & 1 & 2 & 3 \\
\hline $300-309$ & 4. Metal Fabricating & 11 & 10 & 6 & 1 & 4 & 3 & 101 & 11 & 9 & 1 & 2 & 7 & 6 & 9 & 10 & 1 & 2 & 8 \\
\hline $148-269$ & 5. Other Manufactur- & & & & & & & & & & & & & & & & & & \\
\hline $\begin{array}{l}275-299 \\
310-399\end{array}$ & ing & 9 & 8 & 10 & 1 & 2 & 3 & 10 & 61 & 11 & 1 & 2 & 7 & 10 & 8 & & 1 & 2 & 3 \\
\hline 404 & $\begin{array}{l}\text { 6. Construc.-Gen. } \\
\text { Contract. }\end{array}$ & 9 & 6 & 7 & 1 & 2 & 3 & 91 & 101 & 11 & 7 & 3 & 12 & 10 & 9 & 11 & 1 & 2 & 3 \\
\hline 421 & $\begin{array}{l}\text { 7. Construct.-Spec. } \\
\text { Contract. }\end{array}$ & 9 & 7 & 6 & 12 & 1 & 2 & 91 & & 8 & 1 & 2 & 4 & 6 & 7 & 8 & 2 & 1 & 3 \\
\hline $406-409$ & $\begin{array}{l}\text { 8. Construct.- } \\
\text { Engineering }\end{array}$ & 6 & 7 & 5 & 1 & 2 & 3 & 9 & 71 & 10 & 1 & 2 & 3 & 8 & 9 & 10 & 12 & 1 & 2 \\
\hline $500-519$ & 9. Transportation & 12 & 10 & 11 & 1 & 8 & 2 & 10 & 91 & 11 & 8 & 2 & 3 & 11 & 12 & 10 & 1 & 2 & 8 \\
\hline $543-548$ & 10. Communication & 6 & 7 & 8 & 1 & 2 & 3 & 7 & 6 & 8 & 1 & 2 & 4 & 8 & 10 & 12 & 1 & 2 & 3 \\
\hline $\begin{array}{l}520-542 \\
549-579\end{array}$ & $\begin{array}{l}\text { 11. Other Trans., } \\
\text { Comm. \& Util. }\end{array}$ & 11 & 10 & 12 & 1 & 2 & 3 & 7 & 8 & 6 & 1 & 2 & 3 & 6 & 7 & 9 & 1 & 2 & 12 \\
\hline $600-629$ & 12. Wholesale Trade & 10 & 11 & 12 & 1 & 2 & 3 & 11 & 101 & 12 & 1 & 2 & 7 & 10 & 11 & 12 & 1 & 2 & 4 \\
\hline 631 & 13. Food Stores & 12 & 11 & 10 & 8 & 7 & 6 & 12 & 11 & 2 & 7 & 8 & 1 & 12 & 9 & 10 & 7 & 1 & 2 \\
\hline 642 & 14. Dept. Stores & 12 & 11 & 10 & 8 & 7 & 3 & 12 & 111 & 10 & 2 & 7 & 6 & 12 & 11 & 10 & 7 & 8 & 2 \\
\hline $649-699$ & $\begin{array}{l}\text { 15. Other Retail } \\
\text { Trades }\end{array}$ & 12 & 11 & 10 & 1 & 2 & 3 & 11 & 121 & 10 & 2 & 1 & 7 & 12 & 11 & 10 & 1 & 2 & 3 \\
\hline $702-704$ & $\begin{array}{l}\text { 16. Financial } \\
\text { Institutions }\end{array}$ & 10 & 11 & 8 & 1 & 2 & 3 & 12 & 101 & 11 & 1 & 2 & 3 & 12 & 11 & 10 & 1 & 2 & 3 \\
\hline $731-737$ & $\begin{array}{l}\text { 17. Insurance \& } \\
\text { Real Estate }\end{array}$ & 10 & 9 & & 1 & 2 & 3 & 2 & 3 & 1 & 10 & 11 & 4 & 11 & 8 & 9 & 1 & 4 & 2 \\
\hline $861-869$ & 18. Business Services & 10 & 9 & 11 & 2 & 3 & 1 & 12 & 11 & 8 & 4 & 1 & 3 & 8 & 11 & 10 & 1 & 2 & 3 \\
\hline 875 & $\begin{array}{l}\text { 19. Hotels, Rest. } \\
\text { \& Taverns }\end{array}$ & 5 & 6 & 4 & 1 & 2 & 3 & 7 & 101 & 12 & 1 & 2 & 3 & 10 & 9 & 11 & 1 & 2 & 3 \\
\hline $871-874$ & 20. Other Personal & & & & & & & & & & 1 & 2 & 3 & 1 & 4 & 5 & 2 & 3 & 7 \\
\hline 876-879 & $\begin{array}{l}\text { Services } \\
21 \text { Other Services }\end{array}$ & $\begin{array}{r}7 \\
10\end{array}$ & 6 & $\begin{array}{r}12 \\
9\end{array}$ & $\begin{array}{l}1 \\
1\end{array}$ & $\begin{array}{l}2 \\
2\end{array}$ & $\begin{array}{l}3 \\
3\end{array}$ & $\begin{array}{l}6 \\
6\end{array}$ & 8 & $\begin{array}{l}4 \\
5\end{array}$ & $\begin{array}{l}1 \\
1\end{array}$ & $\begin{array}{l}2 \\
2\end{array}$ & 3 & 8 & $\begin{array}{r}4 \\
10\end{array}$ & 7 & 1 & 2 & 3 \\
\hline $\begin{array}{l}851-839 \\
891-899\end{array}$ & i nervices & & & & & & & & & & & & & & & & & & \\
\hline
\end{tabular}


From the above table, it can be seen, for example, that for the Toronto Foods sector the month of peak 1973 employment was June. The next highest total was recorded in July and the third in August. The months of lowest employment in this sector were December, followed by January and February.

Overall, the Manufacturing sectors (\#1-5) tend to peak in the summer and fall months. The Construction sectors (\#6-8) in Toronto tend to maximum employment during the summer months. The industry peaks a bit later in Vancouver and later still in Montreal. Transportation (\#9) attains its highest employment in the fall with sectors 10 and 11 generally reaching somewhat earlier peaks. Maximum employment in Trade sectors $(\# 12-15)$ in all three metropolitan areas occurs in the late fall-early winter. The peak months for Finance, Insurance and Real Estate sectors (\#17-18) come slightly earlier, with the notable exception of the Montreal Insurance and Real Estate sector, which peaks surprisingly during the winter months. The Service sectors (\#18-21) reach their periods of maximum employment anywhere between early summer and early winter.

While the peaks for the various sectors occur at different times during the year, they do occur, almost without exception, during the last half of the year. Of the 189 months listed in Table II as peak months, only 33 fall in the first half of the year and of these 33, 21 are the month of June. In contrast, the months of lowest employment for all sectors appear consistently as the first three months of the year. Of the 189 nadir months, only 39 are months other than January, February and March.

The overall seasonal employment pattern is thus one in which the months of peak employment vary from sector to sector, but occur in the latter half of the year. The period of lowest employment is fairly consistent the first three months of the year. The peaks and troughs are not at all offsetting. ${ }^{6}$

As a first step in the construction of a test of Thompson's second assertion that economic diversity promotes seasonal stability, monthly employment data for the 9 Canadian Metropolitan Areas listed in Table III below were gathered for the years 1971-1973. Given the limitations of the data, only 8 economic sectors ${ }^{7}$ could be constructed that were common to all nine metropolitan areas. From employment data pertaining to these 8 sectors, a simple ogive index of economic diversity, $\mathrm{D}$, was constructed for each metropolitan area in each of the years from equation (3):

$$
\mathrm{D}=\frac{\Sigma\left(\mathrm{P}_{\mathrm{i}}-\mathrm{N}_{\mathrm{i}}\right)^{2}}{\mathrm{~N}_{\mathrm{i}}} \quad \mathrm{i}=1, \ldots, 8
$$

where $\mathrm{P}_{\mathrm{i}}$ is the fraction of total employment in sector $\mathrm{i}$ and $\mathrm{N}_{\mathrm{i}}$, the norm, is the reciprocal of the number of sectors. Since the data are in monthly figures, the calculations were performed on annual averages. This approach to measuring diversity assumes the norm to be a rectangular distribution, which is appropriate in testing any assertion regarding the effect of "random diversification". 8 
Secondly, a simple index of seasonal instability for each economic sector was constructed by calculating the mean absolute deviation from the monthly average and expressing the resulting figure as a percentage of this average. An index of seasonal instability, $\mathrm{s}_{\mathrm{ik}}$, for sector $\mathrm{i}$ in year $\mathrm{k}$ is thus expressed for a particular year as:

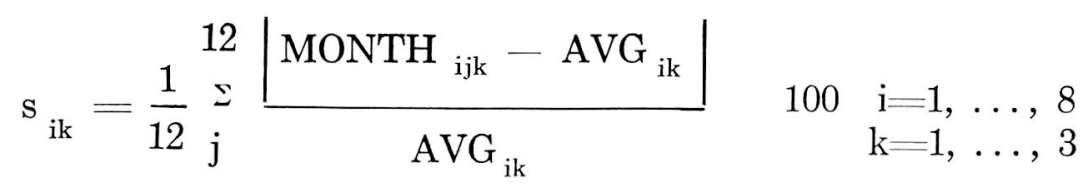

$$
\text { where } A V G_{i k}=\frac{1}{12}{ }_{j}^{12} \text { MONTH }_{\mathrm{ijk}}
$$

In aggregating the above sectoral indices to an overall seasonal instability index for a metropolitan area, each sector was weighted according to its share of total employment in order to reflect the fact that a deviation of $\mathrm{x} \%$ in a sector of mean employment y is considerably more significant in its effect upon the metropolitan economy than the same deviation in a sector with an average employment substantially smaller than $\mathrm{y}$. The metropolitan seasonal instability index, $\mathrm{S}_{\mathrm{k}}$, for year $\mathrm{k}$ was thus formulated as:

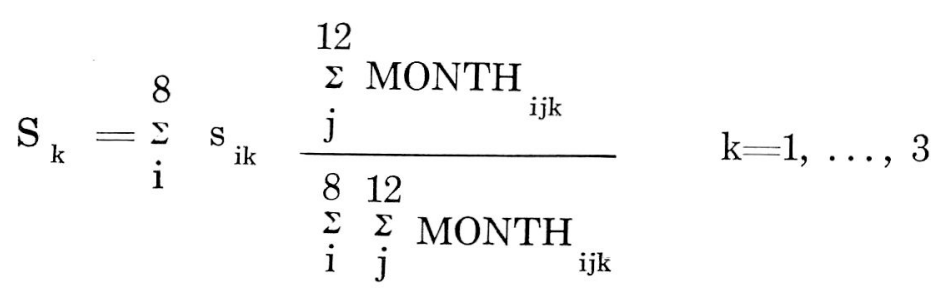

To conclude the testing of the diversity-promotes-stability hypothesis, Spearman's rank correlation coefficient between the sectoral rankings according to stability and diversity respectively was calculated for each of the three years. The results are shown in Table III.

The lower the index of diversity exhibited by a metropolitan economy, the more diverse is the economy, i.e. the more closely it approaches a rectangular distribution of employment. The lower the index of instability, the more seasonally stable is the employment within that economy. For each of the three years shown in Table III, the economies are ranked according to their associated diversity and instability indices. In each case the economy with the lowest index is ranked number 1 . Spearman's rank correlation coefficient was then calculated for each of the years.

If indeed diversity promotes stability, we should expect reasonably high positive values for these coefficients to emerge. To the contrary, however, the correlation coefficients in each of the years is decidedly negative. While admittedly 
TABLE III

Indices of Diversity and Seasonal Instability

for Selected Metropolitan Areas, 1971-1973

\begin{tabular}{|c|c|c|c|c|c|c|c|}
\hline \multirow{3}{*}{\multicolumn{2}{|c|}{$\begin{array}{l}\text { Metropolitan } \\
\text { Area }\end{array}$}} & \multicolumn{2}{|c|}{1971} & \multicolumn{2}{|c|}{1972} & \multicolumn{2}{|c|}{1973} \\
\hline & & $\begin{array}{l}\text { Diversity } \\
\text { Index }\end{array}$ & $\begin{array}{l}\text { Instability } \\
\text { Index }\end{array}$ & $\begin{array}{l}\text { Diversity } \\
\text { Index }\end{array}$ & $\begin{array}{l}\text { Instability } \\
\text { Index }\end{array}$ & $\begin{array}{l}\text { Diversity } \\
\text { Index }\end{array}$ & $\begin{array}{l}\text { Instability } \\
\text { Index }\end{array}$ \\
\hline & & D Rank & S Rank & D Rank & S Rank & D Rank & S Rank \\
\hline 1 & Toronto & .1115 & 2.962 & .1246 & 3.748 & $.094 \quad 2$ & 12.398 \\
\hline 2 & Montreal & $.102 \quad 1$ & 13.799 & .1215 & 2.621 & .0931 & 13.309 \\
\hline 3 & Vancouver & .1074 & 3.756 & .1131 & 3.667 & .1174 & $3.46 \quad 3$ \\
\hline 4 & Calgary & .1042 & $4.50 \quad 8$ & $.117 \quad 3$ & $3.20 \quad 6$ & .1306 & $3.58 \quad 4$ \\
\hline 5 & Edmonton & .1146 & $4.25 \quad 7$ & $.115 \quad 2$ & $\begin{array}{ll}3.87 & 9\end{array}$ & .1063 & 3.725 \\
\hline 6 & London & .1227 & $\begin{array}{ll}3.17 & 3\end{array}$ & .1508 & $2.81 \quad 3$ & .1608 & $3.45 \quad 2$ \\
\hline 7 & Ottawa & $.182 \quad 9$ & $3.23 \quad 4$ & $.206 \quad 9$ & $2.88 \quad 4$ & $.221 \quad 9$ & $4.00 \quad 6$ \\
\hline 8 & Quebec & $.106 \quad 3$ & 3.59 & $.117 \quad 4$ & $2.90 \quad 5$ & . 133 & $4.10 \quad 7$ \\
\hline 9 & Winnipeg & $.140 \quad 8$ & $2.69 \quad 1$ & $.134 \quad 7$ & $2.75 \quad 2$ & $.130 \quad 5$ & $2.92 \quad 1$ \\
\hline & & \multicolumn{2}{|c|}{$\begin{array}{l}\text { Spearman } r_{\mathrm{s}}= \\
-0.733\end{array}$} & \multicolumn{2}{|c|}{$\underset{-0.583}{\text { Spearman }} \mathrm{r}_{\mathrm{s}}=$} & \multicolumn{2}{|c|}{$\begin{array}{l}\text { Spearman } \mathrm{r}_{\mathrm{S}}= \\
-0.417\end{array}$} \\
\hline
\end{tabular}

the data constraints upon our test are severe in that there are only 9 urban economies examined and each is aggregated to eight sectors, the results certainly do not encourage acceptance of the hypothesis that random diversification promotes seasonal economic stability.

\section{SECTORAL SEASONAL INSTABILITY: VARIATIONS BETWEEN METROPOLITAN AREAS}

The purpose of this section is to investigate the extent to which sectors vary in their degree of seasonal instability between metropolitan areas. Again, taking the monthly employment data for the 21-sector economies of Toronto, Montreal and Vancouver, an index of seasonal instability, $\mathrm{s}_{\mathrm{ik}}$, was calculated for each sector in each metropolitan area according to equation (4) for each of the three years 1971-73. An average, $\mathrm{s}_{\mathrm{i}}=\mathrm{s}_{\mathrm{ik}} / 3$, was then determined and the results are shown in Table IV below.

In the above table, each sector is ranked within the metropolitan economy according to its degree of seasonal stability. The pattern is fairly consistent across the metropolitan areas. Each of the six correlation coefficients in Table V is significant at the .01 level.

The Wholesale Trade sector (\#12) emerges as the most seasonally stable sector, ranking no lower than third among the three metropolitan areas. While sales in this sector will fluctuate with shifts in the sales in the Retail Trade sector, the number of customers will be relatively stable and thus employment will be comparatively unchanged. Next in stability are the F.I.R.E. sectors (\#1617), particularly Financial Institutions, the functions of which are largely independent of changes in seasons. The Manufacturing sectors (\#1-5) rank next, 
TABLE IV

AVERAGE INDICES OF SEASONAL INSTABILITY FOR THE MAJOR METROPOLITAN AREAS, 1971-1973

\begin{tabular}{|c|c|c|c|c|c|c|}
\hline \multirow[t]{2}{*}{ ECONOMIC SECTOR } & \multicolumn{2}{|c|}{ TORONTO } & \multicolumn{2}{|c|}{ MONTREAL } & \multicolumn{2}{|c|}{ VANCOUVER } \\
\hline & $\mathbf{s}_{\mathbf{i}}$ & & $\mathbf{s}_{\mathbf{i}}$ & Rank & $\mathbf{s}_{\mathbf{i}}$ & Rank \\
\hline 1. Foods & 1.9 & 5 & 2.1 & 6 & 7.7 & 18 \\
\hline 2. Beverages & 4.4 & 15 & 4.0 & 16 & 6.0 & 15 \\
\hline 3. Paper \& Allied Inds. & 1.4 & 2 & 2.4 & 8 & 2.3 & 4 \\
\hline 4. Metal Fabricating & 2.3 & 8 & 2.0 & 5 & 3.5 & 9 \\
\hline 5. Other Manufacturing & 1.4 & 3 & 1.5 & 4 & 2.5 & 5 \\
\hline 6. Construct.-Gen. Contrct. & 9.1 & 20 & 8.6 & 20 & 11.8 & 21 \\
\hline 7. Construct.-Spec. Contrct. & 5.4 & 18 & 6.3 & 19 & 11.2 & 10 \\
\hline 8. Construct.-Engineering & 14.6 & 21 & 14.3 & 21 & 10.6 & 19 \\
\hline 9. Transportation & 3.2 & 13 & 3.4 & 11 & 4.1 & 10 \\
\hline 10. Communication & 1.9 & 6 & 2.2 & 7 & 2.1 & 3 \\
\hline 11. Other Trans., Comm., Utl. & 4.7 & 17 & 3.4 & 13 & 3.3 & 8 \\
\hline 12. Wholesale Trade & 1.3 & 1 & 1.4 & 3 & 2.1 & 2 \\
\hline 13. Food Stores & 3.0 & 10 & 2.6 & 10 & 2.6 & 6 \\
\hline 14. Dept. Stores & 7.7 & 19 & 6.1 & 18 & 6.3 & 17 \\
\hline 15. Other Retail Trade & 3.6 & 14 & 4.3 & 17 & 4.9 & 13 \\
\hline 16. Financial Institutions & 1.8 & 4 & 1.4 & 2 & 1.8 & 1 \\
\hline 17. Insurance \& Real Estate & 2.0 & 7 & 1.2 & 1 & 4.3 & 11 \\
\hline 18. Business Services & 3.2 & 12 & 2.4 & 9 & 2.9 & 7 \\
\hline 19. Hotels, Rest. \& Taverns & 3.1 & 11 & 3.8 & 15 & 4.8 & 12 \\
\hline 20. Other Personal Services & 2.8 & 9 & 3.4 & 12 & 6.1 & 16 \\
\hline 21. Other Services & 4.5 & 16 & 3.5 & 14 & 5.8 & 14 \\
\hline
\end{tabular}

TABLE V

CORRELATION COEFFICIENTS FOR INDICES OF SEASONAL INSTABILITY FOR THE MAJOR METROPOLITAN AREAS, 1971-1973

\begin{tabular}{lccc}
\hline $\begin{array}{l}\text { CORRELATION } \\
\text { COEFFICIENT }\end{array}$ & $\begin{array}{c}\text { TORONTO- } \\
\text { MONTREAL }\end{array}$ & $\begin{array}{l}\text { MONTREAL- } \\
\text { VANCOUVER }\end{array}$ & $\begin{array}{c}\text { VANCOUVER- } \\
\text { TORONTO }\end{array}$ \\
\hline Simple & .974 & .787 & .745 \\
Rank & .895 & .747 & .732 \\
\hline
\end{tabular}

with Food and Beverages due to the agricultural cycle and climatic changes recording indices significantly higher than those of the other manufacturing industries.

Transportation, Communication and Utilities (\#9-11) rank below manufacturing, presumably due largely to the fluctuations in the Transportation sector which is seasonally much less stable than the Communications sector in each of the metropolitan areas and is undoubtedly subject to greater seasonal fluctuations than are the various utilities. The Service sectors (\#18-21) are next in rank with business services generally more stable than personal services. Below the Service sectors are the Retail sectors which traditionally experience the year-end holiday surge in consumer expenditures. Ranking last in seasonal stability are the Con- 
struction sectors (\#6-8) which are traditionally the most volatile sectors in an urban economy, subject as they are to, among other factors, substantial decreases in activity during the winter season. Only the Department Stores sector in Toronto, sensitive to holiday upswings in purchasing, prevents these sectors from consistently ranking as the least seasonally stable.

\section{CONCLUSIONS}

From the foregoing analyses, the following conclusions may be drawn:

1) Fluctuations in employment in the major urban centres as an economic problem is sufficiently significant to be deserving of the attention of municipal authorities.

2) While the peak months of employment differ between sectors, they generally fall in the latter half of the year. The months of lowest employment for all sectors are fairly consistently the first three months of the year.

3) Promotion of diversification of the economy in a random manner does not lead to seasonal stability in employment.

4) Between the major urban areas, sectors are generally stable in their rankings according to seasonal stability.

Accepting that the problem of urban seasonal unemployment is significant, at least two suggestions for local public policy may be drawn from the above. To the extent that an urban government can influence the level of temporary employment within its jurisdiction, it should support any federal attempts to implement "winter works" programs and perhaps place greater emphasis upon complementing and reinforcing such programs rather than upon the provision of temporary summer jobs. Further, steps should be taken to ensure that any such temporary employment projects are initiated as close as possible to the beginning of the year. Second, in municipal programs for the promotion of new industry for purposes of providing expanded employment, some degree of attention should be directed to the differences in seasonal stability between sectors. A focus upon selected industries may well yield results more desirable than those of a more diffused approach.

\section{FOOTNOTES}

1. Statistics Canada, Employment Earnings and Hours, Catalogue 72-002, Vols. 50-52 (Ottawa, 1972-74).

2. Dominion Bureau of Statistics, Population: Geographical Distributions, Catalogue 92-540 (Ottawa, 1965).

3. Dominion Bureau of Statistics, Standard Industrial Classification Manual (Ottawa, December 1970).

4. See M.G. Kendall and A. Stuart, The Advanced Theory of Statistics (London: Charles Griffin \& Co., 1968), Vol. 3, ch. 46.

5. Thompson, W.R., A Preface to Urban Economics (Baltimore: The Johns Hopkins Press, 1965$),$ p. 147.

6. The single exception to this statement is the previously mentioned Montreal sector of Insurance and Real Estate which peaks in 1973 in the winter months. While this particular sector peaked during approximately the same period in 1972, in 1971 the month of highest employment was September.

7. The eight economic sectors, an aggregation of the previous 21 sectors, are: 1) Durable Goods Manufacturing, 2) Non-Durable Goods Manufacturing, 3) Construction, 4) Transportation, Communication and Other Utilities, 5) Wholesale Trade, 6) Retail Trade, 7) Finance, Insurance and Real Estate and 8) Services.

8. The relevance of measures of economic diversity to urban stability is discussed in $H$. Craig Davis and David E. Baxter, "Diversity Indices and Urban Economic Stability" (unpublished). 